\title{
趣味当先，高效识字 小学语文识字教学研究
}

\author{
石琰 \\ 河北省邯単市丛台区赵都小学
}

DOI:10.32629/jief.v2i8.2155

[摘 要] 识字教学, 作为小学语文教学的基础环节，是从小培养学生听说读写能力的有效方式。在小学语文识字教学中，运用快乐教学的方 式, 能够使识字教学不再枯燥无味, 而是富有趣味性和生动性。快乐识字的方式, 是以学生作为教学主体, 运用故事、儿歌等形式, 引导学 生主动参与教学活动, 从而提升教学质量和效果。

[关键词] 小学: 语文: 识字教学

中图分类号: G623 文献标识码: A

中国汉字文化历史悠久, 博大精深。了解汉字发展进程, 学习好汉 字, 是小学阶段学生学习首要任务。对此, 作为新时代背景下一名小学 语文教师, 要想让小学生具备良好的识字能力, 打造语文识字教学有效 课堂尤为重要。本文就自身教学实践, 通过多种教学途径谈谈小学语文 识字教学, 以期真正提升小学生识字能力, 为语文及其他学科学习良好 基础。

\section{1 构建良好的学习氛围}

小学语文老师要想学生积极主动地参与识字教学, 首先就应该改善 当前的课堂氛围, 让学生在一个轻松、愉快的识字学习氛围中, 积极主 动地去学习。小学生长期处于这种良好的学习氛围下, 不仅能够促进师 生之间的情感交流, 还能够培养学生的自主学习能力。

例如, 在学习《秋天》时, 老师可以让孩子们描述秋天的画面, 让 学生们体验秋天的情境。在《秋天》课文后面有本文重点字词, 老师给 学生营造轻松愉悦的学习氛围, 然后让学生理解和运用词语, 然后老师 对词语进行讲解, 让学生们运用词语造句, 提高学生对词语的运用能力。

\section{2 在具体的语言环境中学习理解, 随文识字}

情境教学具有鲜明的整体性, 随文识字教学也带着一定的整体性。 我们在课文的识字教学中, 不是引导学生孤立地认识一个字, 写一个词, 一般都是在具体的语言环境中进行读写的。这样, 就是我们所说的随文 识字了。例如, 我在教学《清澈的溪水》一课时, 采取随文识字的方法, 运用字理析词, 将生字呈现在具体的语言环境中进行教学, 有助于学生 对课文内容的理解。教学中, 我抓住重点生字 “毁”, 先利用生动的课件, 让学生理解 “毁” 的本意, 再让学生用联系上下文的方法, 理解 “毁” 在文中的含义。同时相机点拨：随意毁坏事物好不好？这使学生在感受 语言文字丰富内涵，感受小兔看到大象、野猪毁坏掉树木时着急、气愤、 生气的心情的同时, 受到人文教育。这一环节的教学, 学生不仅理解了 字义, 也为理解全文作了铺垫。接着, 让学生组词造句, 在运用中巩固 理解 “毁” 字。这样, 学生不仅巩固了识字, 在语言环境中加深对字义 的理解, 而且使学生具体感受到了识字的好处 “识了字, 会说话”, 从而 提高了识字的积极性。

\section{3 开展趣味游戏，提高识字教学效果}

小学低年级学生识字教学效率提升的关键在于调动学生积极性, 让 学生能够喜欢上识字学习, 主动参与到学习当中。而游戏又是低年级学 生十分喜爱的一种方式, 所以在教学实践中, 语文教师应注重趣味游戏 的运用, 比如组织开展游戏识字、谜语识字或者形象识字等多种方式, 让学生在游戏过程中认识汉字、学习汉字。

比如教师可以让学生自己制作生字卡片, 随后让以同桌为单位进行 游戏, 相互抽取对方手中的卡片, 若能够读出卡片中的汉字即可将其取 下, 最后看哪一方的卡片数量多; 或者设置谜语识字游戏, 根据汉字来 设计谜语, 如 “看” 这个字: 一只手遮着眼睛, “碧” 即是: 王婆婆和白 婆婆坐在石头上, 通过设计谜语的方式来让学生对汉字有直观形象的理 解, 也更容易让他们记忆。另外, 教师还可以让学生自己去收集字谜, 同学之间再相互猜谜, 如此一来, 学生不仅积极性较高, 同时也可以掌 握更多的汉字。

4 增强情境互动, 提高学生参与积极性

在情境性课堂开展过程中，教师还应加强情境互动，包括师生之间
的互动, 学生之间的互动, 以增强情境性课堂开展的趣味性, 营造良好 的课堂氛围, 提高学生参与的积极性。

例如可以开展 “猜字游戏”, 即由一名学生表演摆出汉字的造型或者 对汉字的含义进行描述, 其他小组成员猜字, 这样就大大增加了学生之 间的有效互动, 而且还可以加强识字教学的趣味性, 使学生掌握更多的 生字。又如还可以开展 “加一笔” 的游戏, 在汉字中加一笔, 使其变成 一个新的汉字, “日” 加一笔, 可以变成很多的汉字, 如 “目、白、田、 甲” 等等, 这样能够使学生认识更多的汉字, 而且不需要死记硬背, 激 发了学生对识字的兴趣。

\section{5 观察课后, 鼓励自主学习}

小学识字教学其主要目的是培养学生字词应用能力, 以字形、字音、 字义为要素的语言教学过程, 通常与词汇教学相结合, 是新《义务教育 语文课程标准》规定的内容之一，也是少年儿童传承中国传统文化的基 本途径。为了让小学生学好汉字, 达到小学语文识字教学的教学目标, 除了课中需要注意的事项, 作为教师, 还应该加强关注学生的课后表现, 鼓励他们进行主动学习。教师可以留下关于识字的课后作业, 让学生每 天学习一个自己不认识的字, 并进行第二天的课堂提问。也可以让学生 主动写下自己新学的字, 然后与其他同学进行交流并交换, 学会的字可 以与自己不认识的字进行交换, 并向认识这个字的同学请教, 学会之后 再寻找自己不认识的字, 再进行交换, 如此反复, 每天进行。这样做, 既加强了学生与学生之间的交流, 又充分发挥了学生的主体参与作用, 提高了学习效率和自主性

\section{6 通过拼音学习, 加深对汉字的认识}

小学阶段的拼音教学看着很简单, 但是实际操作起来非常难。在面 对声母与韵母的相关知识时, 学生学习起来觉得非常吃力, 基础内容如 果学不好, 就会影响到识字教学的有序开展。通过教学实践证明, 学生 的拼音学的不好, 在扩展汉字数量时, 学生就会因为拼音基础不好, 当 面对一些生字时, 就算上面标注了拼音也不会读出来汉字的发音, 对于 汉字的后续学习更是吃力。为了解决这个问题的出现, 在得到家长的配 合下, 引导学生多阅读带有拼音的儿童书籍, 通过这样的方式培养学生 的阅读兴趣, 当出现读错的时候, 需要及时的改过来。在识字实际教学 中应该选择熟悉的字进行学习, 由于学生认识这个字, 所以就算没有拼 音也会读出来, 但是需要学生观察拼音的拼写, 之后再考察学生对陌生 字的情况, 只要表现的努力就会得到表扬, 教师要帮助学生客服畏惧的 情绪。

教师应努力从创建多元化教学课堂的角度出发, 提高课堂教学效率, 提高学生的识字效果。

\section{[参考文献]}

[1]沈雪珺.基于部编版教材培养低段小学生语文素养的策略探究 [J].课程教育研究,2019(52):175-176.

[2]陈丹凤.有效开展语文综合实践 全面培养学生语文素养[J].学周 刊,2018(81):98-99.

[3]徐娜娜.浅析小学语文教学课堂读写训练策略 [J]. 新课 程,2020(34):39. 